UDC 612.128; 612.115

doi: https://doi.org/10.15407/ubj90.05.060

\title{
OVERALL HEMOSTASIS POTENTIAL OF THE BLOOD PLASMA AND ITS RELATION TO SOME MOLECULAR MARKERS OF THE HEMOSTASIS SYSTEM IN PATIENTS WITH CHRONIC RENAL DISEASE OF STAGE VD
}

\author{
B. G. STOROZHUK ${ }^{1}$, L. V. PYROGOVA', T. M. CHERNYSHENKO', \\ O. P. KOSTIUCHENKO ${ }^{2}$ I. M. KOLESNIKOVA ${ }^{2}$, T. M. PLATONOVA ${ }^{2}$, \\ O. B. STOROZHUK ${ }^{1}$, L. O. STOROZHUK ${ }^{1}$, G. K. BEREZNITSKY ${ }^{2}$, \\ P. YU. TSAP ${ }^{2}$, O. O. MASENKO', E. M. MAKOGONENKO ${ }^{2}$, E. V. LUGOVSKOY ${ }^{2}$

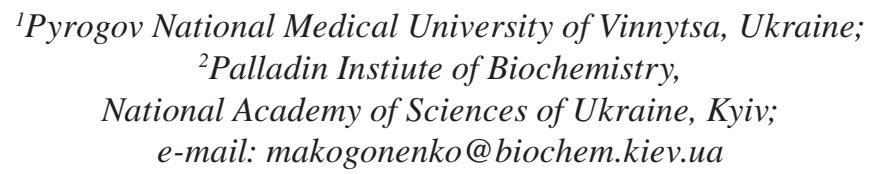

The values of the coagulation, overall and fibrinolysis potentials were estimated by the method of the global potential of Blomback M., as well as the values of concentrations of molecular markers of the hemostasis system: soluble fibrin (sf), D-dimer, fibrinogen (Fg) and protein C (88 patients, 52 of them men, 36 women). It was shown that hemostasis system activity in women plasma is higher than that in men plasma. The division of patients into 3 groups, depending on the concentration of $s f$ : less than normal $-s f \leq 3$, about norm $3<s f<4$ and more than norm $-s f>4 \mu \mathrm{g} / \mathrm{ml}$, allowed establishing the growth of the parameters of both the hemostatic potential and concentrations of molecular markers in accordance with concentration of sf in the groups of patients. Paerson's correlation analysis of the relationship between the parameters of the hemostasis potential and concentrations of molecular markers revealed an increase in the correlation relationship to the strong and very strong between the parameters of coagulation, fibrinolysis and protein C systems with an increase in the concentration of soluble fibrin in plasma of patients.

Ke y wo rds: hemostasis potential of plasma, soluble fibrin, D-dimer, fibrinogen, protein C.

$\mathrm{H}$ emostasis in humans is carried out by a system of coagulation or blood clotting. Normally, it is responsible for the integrity of the blood vessels and the organism as a whole, being activated for a short time to close the lesions by forming blood clots. In pathological conditions when procoagulant agents of external or internal origin enter the blood, long-term activation of the blood coagulation system occurs and the patient may be at risk of thrombosis. Long-term activation of the system of coagulation leads to the constant formation of thrombin in the bloodstream, which takes place in chronic diseases. Thrombin is a multifunctional enzyme [1]. On the one hand, it activates platelets and fibrinogen to form soluble fibrin, stimulates its own activation by proteolytic cleavage of FVIII, FV, FXI, as well as TAFI (thrombin activated fibrinolysis inhibitor), which removes C-terminal lysines in plasmin-dissolving fibrin, and inhibits fibrinolysis. On the other hand, thrombin activates protein $\mathrm{C}$ which cleaves FVIIIa and FVa, and together with TFPI (tissue factor pathway inhibitor) and ATIII + He inhibits the formation of thrombin [2]. Long-term activation of coagulation has not a certain physiological direction, it initiates activation of functionally related systems, induces the hemostatic factors consumption, creating a threat to thrombosis or DIC syndrome in patients [3]. Therefore, the purpose of our work was to estimate the level of connection between the activity of the system of coagulation and the activity of systems of protein $\mathrm{C}$ and fibrinolysis in chronic diseases on the example of CKD, VD stage (glomerulonephritis).

(C) 2018 Storozhuk B. G. et al. This is an open-access article distributed under the terms of the Creative Commons Attribution License, which permits unrestricted use, distribution, and reproduction in any medium, provided the original author and source are credited. 
In the previous article, we found that between the parameters of the hemostasis potential determined by the method of M. Blomback [4], which show the ability of blood plasma hemostasis system in vitro to form and dissolve the fibrin clot, and molecular markers of the hemostasis system in plasma of blood in vivo, which characterize the state of the hemostasis system at the moment of the blood sample withdrawing in patients with myocardial infarction, stroke or hip joint disease, no strong correlation was observed [4].

In the paper we present the results of analysis of the hemostasis potential parameters and concentrations of molecular markers in the plasma hemostasis system in patients with chronic kidney disease (CKD, VD stage (glomerulonephritis)). In order to determine the presence or absence of interconnections between the parameters of these systems in blood plasma and concentrations of molecular markers characterizing the relations of the coagulation, fibrinolysis and protein $\mathrm{C}$ system, Pearson's pairwise correlation analysis was performed between the values of these parameters. All examined patients were divided into subgroups, depending on their sex and concentration of soluble fibrin in the blood plasma, which reflected the degree of activation of the humoral component of the hemostasis system in vivo, and which allowed us to identify the hidden links between the components of the latter. In the subgroups of men and women, where the correlation relationship was found, the correlation coefficients were significantly increasing with the increase of concentrations of soluble fibrin from the weak $(<0.5)$ and mean $(0.5-0.7)$ to strong $(>0.7)$ and very strong $(>0.9)$ values. This approach allows more differentiated analysis of the patients' hemostasis system state in various diseases and more consistent with the principles of 4P medicine, which considers blood as a "window in health and human disease" [5].

\section{Materials and Methods}

The APTT (activated partially thromboplastin time) reagent (Renam, $R F$ ), recombinant tissue plasminogen activator (t-PA) from Boehringer Ingelheim (Germany) were used. Samples of blood (CKD VD stage (glomerulonephritis)) were withdrawn in 3.8\% sodium citrate (1 part of sodium citrate, $\mathrm{pH} 7.4$, and 9 parts of blood). The permission of the Ethics Commission of the E.I. Pirogov Vinnitsa National Medical University to conduct blood-related research and informed consent from each patient were obtained.
Blood samples were taken in patients prior to the hemodialysis procedure. The plasma was separated from the blood cells within 1 hour after blood collection by centrifugation of the latter at $3000 \mathrm{~g}$ for $20 \mathrm{~min}$. Plasma aliquots were stored at $-20^{\circ} \mathrm{C}$.

The plasma hemostasis potential was determined by spectrophotometric method, recording the absorbance of light by fibrin clot at $405 \mathrm{~nm}$ on the Multiscan microrider (Finland). The clots were formed in microplate wells in which 0.05 M HEPES buffer, $\mathrm{pH} 7.4$, containing $0.15 \mathrm{M} \mathrm{NaCl}(30$ or $27 \mu \mathrm{l})$, $70 \mu \mathrm{l}$ of blood plasma, t-PA to a final concentration of $75 \mathrm{IU} / \mathrm{ml}(3 \mu \mathrm{l})$ and APTT reagent $(100 \mu \mathrm{l})$ were sequentially added. The plasma coagulation was initiated by $25 \mathrm{mM} \mathrm{CaCl}_{2}(100 \mu \mathrm{l})$. Final volume of the reaction mixture was $300 \mu \mathrm{l}$. The overall hemostasis potential (OHP) is characterized by the size of area under curve of the clot turbidity from the moment the plasma coagulation is initiated to the moment when turbidity completely disappeared in the presence of t-PA. Coagulation potential (CP) is the area under curve of the clot formation in the absence of t-PA from the moment of plasma coagulation initiation to the moment of complete dissolution of the clot in the presence of t-PA. Fibrinolysis potential (FP) is the difference between the magnitudes of $\mathrm{CP}$ and OHP. All values of potentials are expressed in units of optical density multiplied by time in seconds (o. u.s) $[4,6]$.

Concentration of fibrinogen, soluble fibrin and D-dimer in plasma was determined using an enzyme-linked immunoassay test systems developed at the Palladin Institute of Biochemistry of the NAS of Ukraine [7, 8], and the level of protein C using the test system of Renam company (RF). Statistical processing of the results was carried out using the standard statistical program in Excel. The mean values of parameters and their standard deviations were determined, pair correlation analysis was performed and reliability of difference between the mean values of two groups according to Student's test was determined.

\section{Results and Discussion}

General description of the state of hemostasis in patients with CKD VD stage (glomerulonephritis) that periodically undergo hemodialysis. The total number of examined patients was 88, of which 52 were men and 36 - women. To determine the parameters of plasma hemostasis potential of each patient, curves for changes in light absorbance in the 
process of blood plasma coagulation, initiated by a APTT reagent in the t-PA absence and presence, were obtained. The averaged experimental curves and their standard deviations for patients in these groups are presented in Fig. 1, A, B, C. On the basis of coagulation curves of each patient blood plasma, parameters of the hemostasis system in vitro, which include lag period, maximal turbidity of the clot, time of clot existence and its half-dissolution, and initial turbidity of plasma were determined. Together with concentrations of molecular markers, namely soluble fibrin (sf), fibrinogen (Fg), D-dimer (DD) and protein $\mathrm{C}(\mathrm{PC})$, they are given in Table 1 as mean parameter values and their standard deviations $(X \pm m)$.

The data presented in Table 1 indicate that the values of all parameters except lag period and Ho in women tend to be slightly higher than those of men, but this difference is not statistically significant for all parameters. Attention is drawn to the same values of lag-periods of blood clotting in all patients. This indicates the same rate of the internal pathway activation of plasma blood coagulation in men and women, the same rate of thrombin and protofibrils formation [9]. However, the maximal turbidity of the clot is significantly higher in women, indicating a greater thickness of fibrils in fibrin clots [10]. Similar clots stimulate more efficiently the activation of plasminogen by t-PA. CP, OHP, and FP in women are also higher, indicating a larger plasma clot in women and a slightly different fibrin mesh structure of clot. Since fibrinogen concentrations are the same in men and women plasma, these differences can be explained by the increased inclusion of additional proteins in women's fibrin structure, possibly, such as fibronectin, fibrinolysis inhibitors and fibrinolytic system components - plasminogen, t-PA, PAI-1 and $\alpha 2$-antiplasmin [11-13]. FXIIIa, which covalently crosslinks soluble fibrin molecules through the $\gamma$-chains [14] and attaches the fibrinolytic inhibitors (PAI-1 and $\alpha 2$-antiplasmin) to the $\alpha \mathrm{C}$ regions, is, probably, involved in this process. In men and women plasma the level of soluble fibrin exceeds the cut-off level $(3 \mu \mathrm{g} / \mathrm{ml})$, which is usually associated with the increased activity of blood coagulation system in patients. However, concentration of soluble fibrin in women is significantly higher than that in men. The concentration of D-dimer in all patients does not exceed the level of cut-off $(90 \mathrm{ng} / \mathrm{ml})$, but in women it is 1.5 times higher than in men. Fg concentration was slightly higher than the upper limit of the normal range $(4 \mathrm{mg} / \mathrm{ml})$. Protein $\mathrm{C}$ system in patients
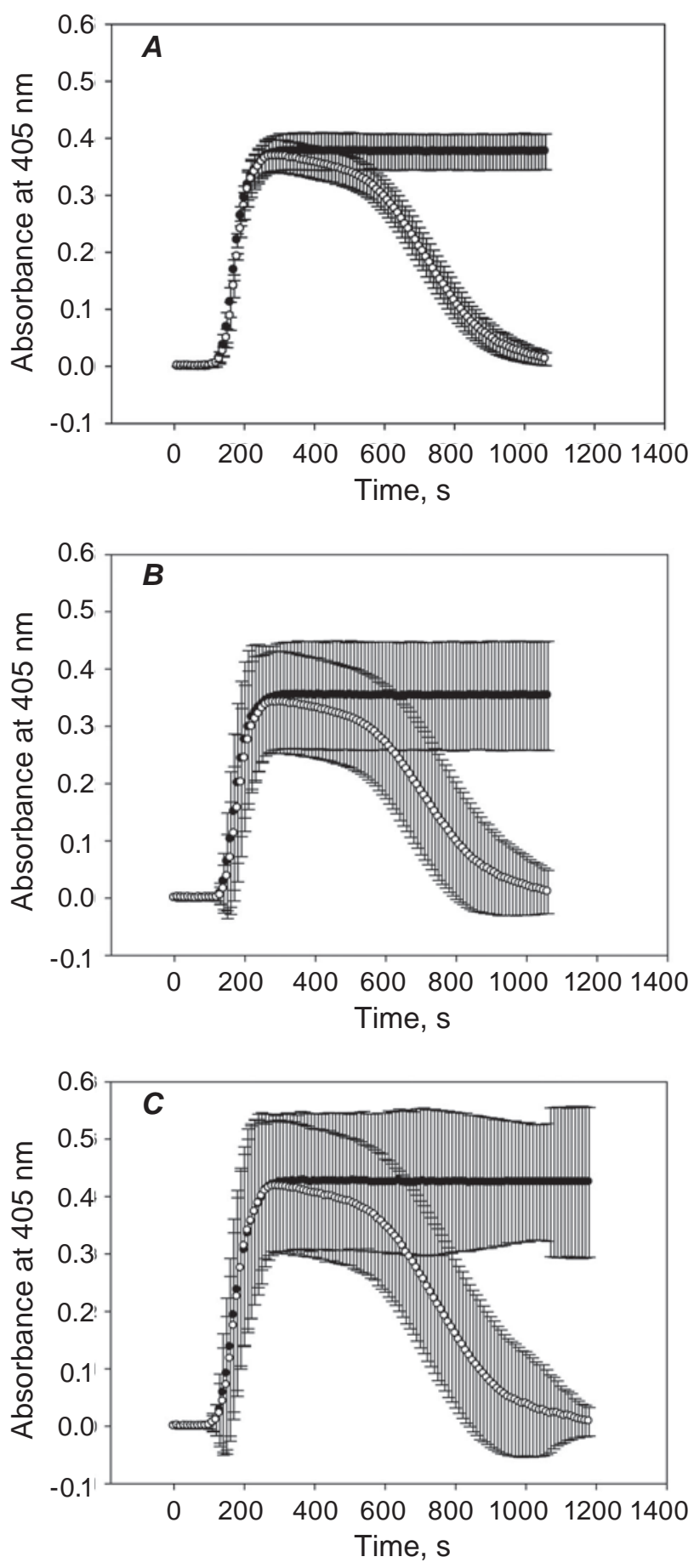

Fig. 1. The coagulation curves for plasma of patients with CKD of the VD stage undergoing hemodialysis, activated by the APTT reagent, in the absence (ascending on plateau) and in the presence of $t-P A$ (ascending-descending). $\boldsymbol{A}-$ all patients $(n=88)$, $\boldsymbol{B}-$ men $(n=52), \boldsymbol{C}-$ women $(n=36)$

is also in activated state, and in women the level of protein $\mathrm{C}$ consumed is significantly lower than that in men (Table 1). 
Thus, the data obtained indicate an increased activity of coagulation and fibrinolysis systems in women compared with that in men. In men, the protein $\mathrm{C}$ system is activated significantly more than in women. Eventually, the hemostasis system in all patients with CKD VD stage (glomerulonephritis) has increased activity that is consistent with the presence of inflammatory process in patients with chronic kidney disease.

In case of inflammatory process in patients the plasma coagulation system is activated primarily due to the appearance of microvesicles containing tissue factor - the initiator of triggering the external pathway of blood coagulation [3]. The main molecular marker of coagulation system activation and its product is a soluble fibrin [15]. Soluble fibrin is revealed in the circulation in a form of short oligomers, in which molecules of desA fibrin and its $\mathrm{X}$-fragments are covalently crosslinked by FXIIIa [15]. Oligomers of desA fibrin are not able to stimulate the activation of plasminogen with t-PA [16]. It is believed D-fragments are formed in capillaries where the blood velocity falls by two to three orders and the fibrin oligomers associate into fibrils, at the surface of which a plasminogen-t-PA activator complex is formed to produce plasmin, which dissolves microclots with the release of D-dimer fragments [17]. Therefore, the D-dimer is a marker of activation of both the coagulation and fibrinolytic processes in the humoral component of hemostasis system of the blood. It should be noted that the ratio of concentrations of soluble fibrin and D-dimer is considered as important indicator of the threat of thrombotic complications of surgical interventions [18].

Since the level of soluble fibrin in patients fluctuated significantly, we divided the patients into three groups in correspondence to the level of activation of patient's coagulation system: a) patients with a concentration of soluble fibrin equal to or less than $\mathrm{sf} \leq 3 \mu \mathrm{g} / \mathrm{ml}$; b) with a concentration close to the norm $-3<\mathrm{sf}<4 \mu \mathrm{g} / \mathrm{ml}$, and with an increased concentration $-\mathrm{sf}>4 \mu \mathrm{g} / \mathrm{ml}$ (Table 2, Fig. 2, 3, 4).

For the plasma hemostasis potential parameters in vitro such distribution of patients showed the next: a) lag period of clot formation has not changed for all groups of patients with increasing the degree of the coagulation system activation; b) turbidity of the clot (mass/length ratio) [19] in men does not increase in the absence and presence of t-PA, but in women it significantly increases (1.46 and 1.49 times, respectively) that can be explained by a greater activation of FXIII in women with covalent incorporation of other proteins in the clot, and elevated levels of soluble fibrin; c) clot lifetime in the presence of t-PA does not change in men in vitro, while in women the clot lifetime is significantly increased (1.19 times),

Ta b le 1. Values of parameters of hemostasis potential, concentrations of soluble fibrin, D-dimer, fibrinogen and protein $C$ in blood plasma of patients with CKD of VD stage (glomerulonephritis) undergoing hemodialysis (men $-n=52$, women $-n=36$, all patients $-n=88$ ). The data are presented as $X \pm m$ and an assessment of the reliability of difference between values of parameters in men and women

\begin{tabular}{l|c|c|c|c|c|c|c}
\hline \multirow{2}{*}{ Parameters } & \multicolumn{2}{|c|}{ In the absence of t-PA } & \multicolumn{5}{c}{ In the presence of t-PA } \\
\cline { 2 - 8 } & $\mathrm{t}, \mathrm{s}$ & $\mathrm{H}$, o.u. & $\mathrm{t}, \mathrm{s}$ & $\mathrm{H}, \mathrm{o} . \mathrm{u}$ & $\mathrm{L}, \mathrm{s}$ & $\mathrm{T}, \mathrm{s}$ & Ho, o.u. \\
\hline Men & $155 \pm 24$ & $0.36 \pm 0.10$ & $159 \pm 25$ & $0.35 \pm 0.10$ & $726 \pm 104$ & $584 \pm 103$ & $0.38 \pm 0.14$ \\
Women & $153 \pm 33$ & $0.42 \pm 0.12$ & $155 \pm 31$ & $0.42 \pm 0.12$ & $764 \pm 110$ & $573 \pm 99$ & $0.35 \pm 0.15$ \\
& n.s. & $P<0.05$ & n.s. & $P<0.05$ & n.s. & n.s. & n.s. \\
All patients & $153 \pm 28$ & $0.39 \pm 0.11$ & $157 \pm 28$ & $0.38 \pm 0.11$ & $741 \pm 107$ & $580 \pm 104$ & $0.37 \pm 0.15$ \\
\hline Parameters & $\mathrm{CP}$, o.u. & OHP, o.u. $\cdot \mathrm{s}$ & FP, o.u. $\cdot \mathrm{s}$ & $\mathrm{Sf}, \mu \mathrm{g} / \mathrm{ml}$ & $\mathrm{DD}, \mathrm{ng} / \mathrm{ml}$ & $\mathrm{Fg}, \mathrm{mg} / \mathrm{ml}$ & $\mathrm{PC}, \%$ \\
\hline Men & $278 \pm 132$ & $188 \pm 83$ & $95.4 \pm 62.1$ & $3.5 \pm 1.1$ & $61.6 \pm 32.1$ & $4.13 \pm 0.15$ & $80.5 \pm 2.0$ \\
Women & $342 \pm 143$ & $238 \pm 95$ & $104.0 \pm 54.1$ & $4.0 \pm 2.5$ & $96.0 \pm 98.7$ & $4.20 \pm 0.21$ & $83.4 \pm 2.9$ \\
& $P<0.05$ & $P<0.01$ & $P \leq 0.05$ & $P<0.05$ & $P<0.05$ & n.s. & $P<0.001$ \\
All patients & $303 \pm 139$ & $208 \pm 91$ & $98.9 \pm 58.9$ & $3.7 \pm 1.8$ & $75.3 \pm 68.6$ & $4.15 \pm 0.17$ & $81.7 \pm 1.7$ \\
\hline
\end{tabular}

Here and in the Table 2-3: $\mathrm{t}$ - lag period of plasma coagulation ( $\mathrm{s}$ - seconds); $\mathrm{H}$ - maximal turbidity of the clot (o.u. optical absorption units at $405 \mathrm{~nm})$; $\mathrm{L}$ - time of half-dissolution of the clot; $\mathrm{T}$ - the time of clot existence $(\mathrm{T}=\mathrm{L}-\mathrm{t})$; Ho - initial turbidity of plasma; CP, OHP, FP - coagulation, overall hemostasis, fibrinolysis potential of blood plasma; sf - soluble fibrin; DD - D-dimer; Fg - fibrinogen; PC - Protein C; n.s. - statistically unreliable difference. 
Ta ble 2. The values of parameters of hemostasis potential, concentration of soluble fibrin, D-dimer, fibrinogen and protein C in blood plasma of patients with the CKD of the VD stage (glomerulonephritis) undergoing hemodialysis. Each group of patients (men-52, women-36, all patients - 88) is divided into three subgroups, depending on the concentration of soluble fibrin in blood plasma: 15 men and 13 women with a concentration of $s f<3 ; 25$ men and 13 women with a concentration of $3<s f<4 ; 12$ men and 10 women with a concentration of $s f>4(X \pm m)$. Reliability of the difference between the parameter values in men and women is assessed

\begin{tabular}{|c|c|c|c|c|c|c|c|}
\hline Parameters & $\mathrm{t}, \mathrm{s}$ & H, o.u. & $\mathrm{t}, \mathrm{s}$ & $\mathrm{H}, \mathrm{o.u}$ & $\mathrm{L}, \mathrm{s}$ & $\mathrm{T}, \mathrm{s}$ & Ho, o.u \\
\hline \multicolumn{8}{|c|}{ Men } \\
\hline sf $<3$ & $150 \pm 25$ & $0.34 \pm 0.09$ & $155 \pm 27$ & $0.33 \pm 0.09$ & $699 \pm 68$ & $548 \pm 66$ & $0.37 \pm 0.14$ \\
\hline $3<\mathrm{sf}<4$ & $154 \pm 20$ & $0.38 \pm 0.10$ & $158 \pm 19$ & $0.38 \pm 0.10$ & $746 \pm 97$ & $591 \pm 96$ & $0.37 \pm 0.15$ \\
\hline \multirow[t]{2}{*}{$\mathrm{sf}>4$} & $157 \pm 37$ & $0.40 \pm 0.09$ & $162 \pm 37$ & $0.37 \pm 0.11$ & $758 \pm 138$ & $600 \pm 124$ & $0.36 \pm 0.10$ \\
\hline & n.s. & n.s. & n.s. & n.s. & n.s. & n.s. & n.s. \\
\hline \multicolumn{8}{|c|}{ Women } \\
\hline $\mathrm{sf}<3$ & $153 \pm 21$ & $0.30 \pm 0.07$ & $160 \pm 25$ & $0.29 \pm 0.07$ & $763 \pm 60$ & $520 \pm 57$ & $0.30 \pm 0.17$ \\
\hline $3<\mathrm{sf}<4$ & $160 \pm 42$ & $0.43 \pm 0.14$ & $159 \pm 37$ & $0.42 \pm 0.13$ & $786 \pm 116$ & $626 \pm 110$ & $0.36 \pm 0.18$ \\
\hline \multirow[t]{2}{*}{$\mathrm{sf}>4$} & $148 \pm 23$ & $0.44 \pm 0.14$ & $153 \pm 24$ & $0.44 \pm 0.15$ & $776 \pm 144$ & $618 \pm 134$ & $0.34 \pm 0.16$ \\
\hline & n.s. & $P<0.001$ & n.s. & $P<0.001$ & n.s. & $P<0.05$ & n.s. \\
\hline Parameters & $\mathrm{CP}$, o.u. $\mathrm{s}$ & OHP, o.u.s & FP o.u. $\cdot$ s & $\mathrm{sf}, \mu \mathrm{g} / \mathrm{ml}$ & $\mathrm{DD}, \mathrm{ng} / \mathrm{ml}$ & $\mathrm{Fg}, \mathrm{mg} / \mathrm{ml}$ & $\mathrm{PC}, \%$ \\
\hline \multicolumn{8}{|c|}{ Men } \\
\hline $\mathrm{sf}<3$ & $243 \pm 85$ & $169 \pm 60$ & $79 \pm 39$ & $2.50 \pm 0.32$ & $45 \pm 30$ & $3.95 \pm 1.18$ & $82.7 \pm 15.0$ \\
\hline $3<\mathrm{sf}<4$ & $305 \pm 128$ & $213 \pm 78$ & $97 \pm 62$ & $3.50 \pm 0.28$ & $69 \pm 27$ & $4.50 \pm 1.00$ & $83.2 \pm 15.0$ \\
\hline \multirow[t]{2}{*}{$\mathrm{sf}>4$} & $323 \pm 170$ & $265 \pm 108$ & $122 \pm 74$ & $4.9 \pm 1.2$ & $77 \pm 37$ & $3.86 \pm 0.83$ & $77.0 \pm 12.0$ \\
\hline & n.s. & $P<0.01$ & n.s. & $P<0.001$ & $P<0.05$ & $P<0.05$ & n.s. \\
\hline \multicolumn{8}{|c|}{ Women } \\
\hline sf $<3$ & $203 \pm 121$ & $138 \pm 39$ & $74 \pm 45$ & $2.50 \pm 0.36$ & $38 \pm 24$ & $3.9 \pm 1.3$ & $78.4 \pm 15.0$ \\
\hline $3<\mathrm{sf}<4$ & $367 \pm 172$ & $251 \pm 106$ & $116 \pm 72$ & $3.6 \pm 0.3$ & $62 \pm 39$ & $4.4 \pm 1.4$ & $80.8 \pm 16.0$ \\
\hline \multirow[t]{2}{*}{$\mathrm{sf}>4$} & $358 \pm 161$ & $251 \pm 116$ & $107 \pm 46$ & $6.6 \pm 3.4$ & $190 \pm 137$ & $4.0 \pm 1.4$ & $81.6 \pm 21.0$ \\
\hline & $P<0.01$ & $P<0.01$ & n.s. & $P<0.01$ & $P<0.05$ & n.s. & n.s. \\
\hline
\end{tabular}
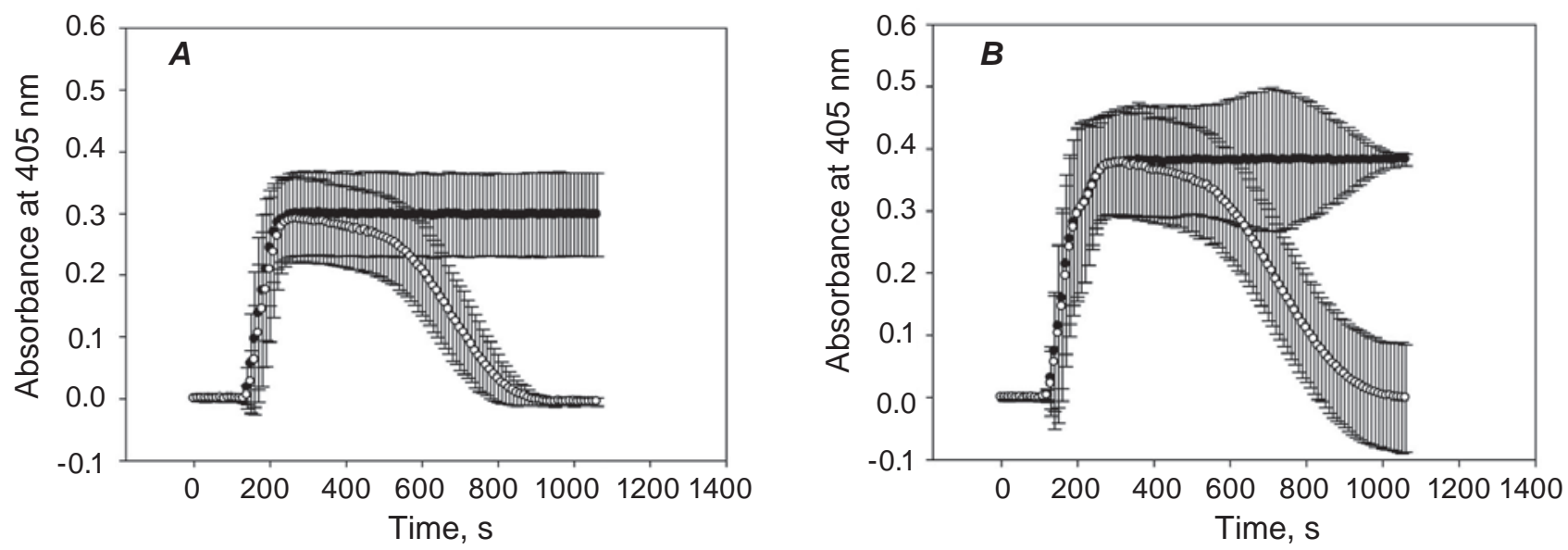

Fig. 2. The coagulation curves for plasma of men (A) and women (B) with levels of $s f<3 \mu \mathrm{g} / \mathrm{ml}$ activated by APTT reagent, in the absence (ascending on plateau) and in the presence of t-PA (ascending-descending) (15 men and 13 women) 

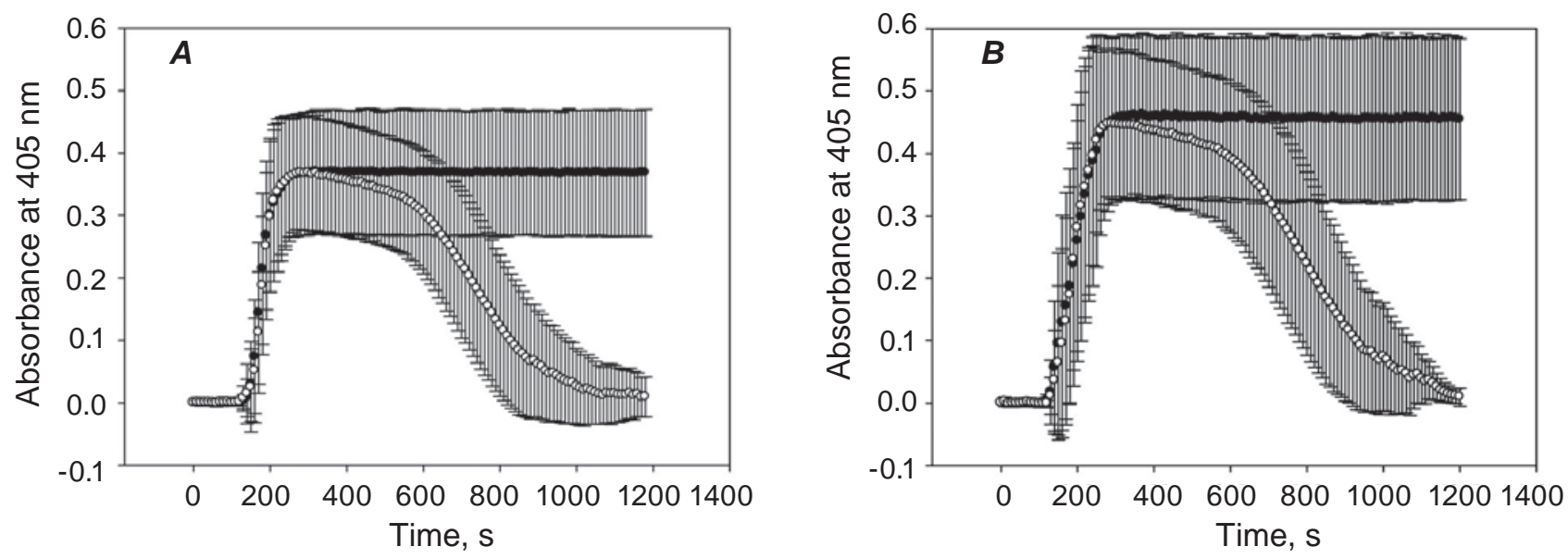

Fig. 3. The coagulation curves for plasma of men (A) and women (B) with a level of $3<s f<4 \mu \mathrm{g} / \mathrm{ml}$ activated by the APTT reagent, in the absence (ascending on the plateau) and in the presence of t-PA (ascendingdescending), (25 men and 13 women)

indicating an enhancement of fibrinolysis inhibitors content in the clot (possibly due to $\alpha 2$-antiplasmin and PAI-1 crosslinking); d) initial turbidity of men and women plasma does not change; e) the values of $\mathrm{CP}$ and $\mathrm{FP}$ in men plasma do not change, but OHP increases 1.57 times; in women $\mathrm{CP}$ and OHP increase 1.76 and 1.82 times, respectively that also indicates a larger mass/length ratio of fibrils in women plasma, compared with that in men. The FP in both groups remains unchanged.

For molecular markers of the blood plasma hemostatic system in vivo, Table 2, it was found that: a) the level of soluble fibrin and D-dimer in men increases 1.96 and 1.71 times, and in women - 2.64 and 5 times in groups of level sf $>4$, respectively that shows a greater activity of coagulation and fibrinolytic systems in women than in men; b) DD/sf ratio in men decreases insignifically from 18 at $\mathrm{sf}<3$ to 15.7 at $\mathrm{sf}>4$, while in women it increases from 15.2 to 28.8 that confirms our assumption of a greater efficiency and balance of coagulation and fibrinolysis systems in women; c) the level of fibrinogen in men in groups with $\mathrm{sf}<3$ and $\mathrm{sf}>4$ is within the normal range, at $3<\operatorname{sf}<4$ it slightly exceeds it, and at $\mathrm{sf}>4$ - returns to the normal level; given that fibrinogen is an acute phase protein, we can assume that in men with $\mathrm{sf}<3$ inflammation is weakly expressed, with $3<\mathrm{sf}<4$ - its initial stage takes place, and with $\mathrm{sf}>4$ is a more active stage, since there is an effect of protein "consumption" of the hemostasis
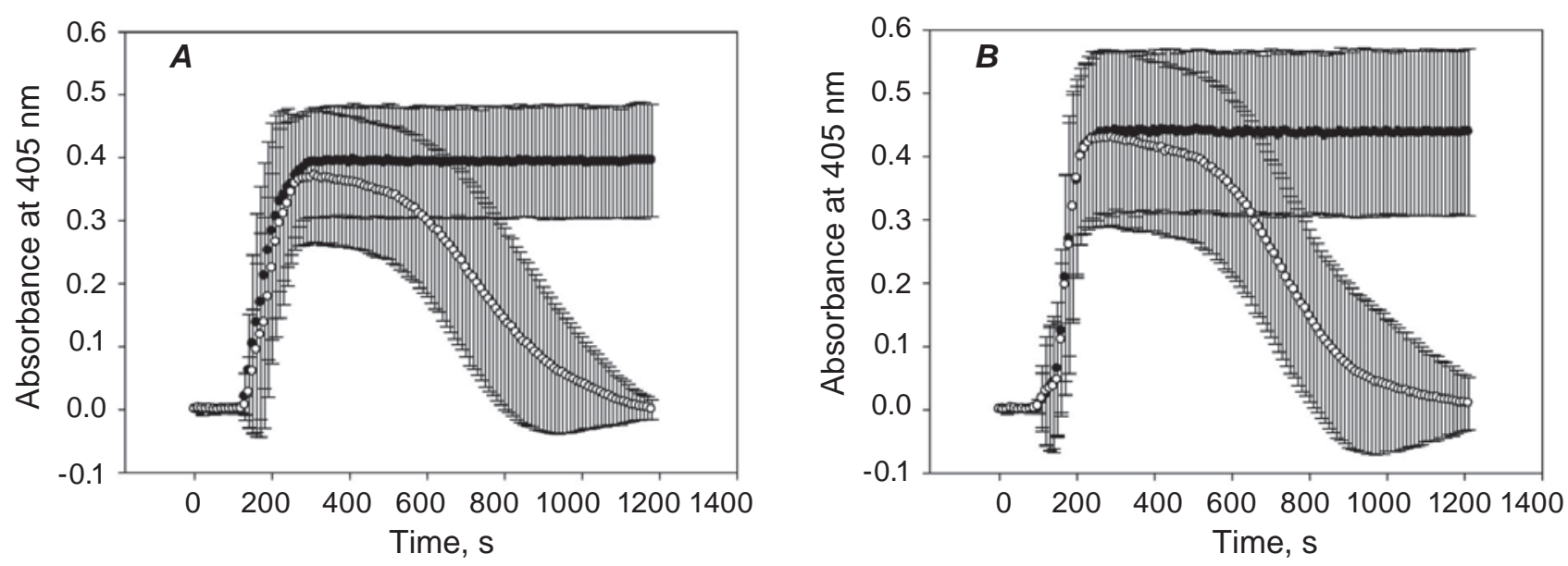

Fig. 4. The coagulation curves for plasma of men (A) and women (B) with a level of $s f>4 \mu \mathrm{g} / \mathrm{ml}$ activated by the APTT reagent, in the absence (ascending on the plateau) and in the presence of t-PA (ascending-descending), (12 men and 10 women) 
system on the example of fibrinogen; d) the parameters of protein $\mathrm{C}$ system in men and women vary by chance, but in both groups it is possible to note the increased activity of protein $\mathrm{C}$ system. The data presented in Table 1 and Table 2 allow suggesting that at $\mathrm{sf}>4 \mu \mathrm{g} / \mathrm{ml}$ the growth of fibrin concentrations is controlled by fibrinolytic system in women (level DD dimer is $\sim 190 \mu \mathrm{g} / \mathrm{ml}$, in men it is $\sim 77 \mu \mathrm{g} / \mathrm{ml}$ ), however in men - by the system of protein $\mathrm{C}$ (Table 1) that is indicated by a higher level of protein $C$ consumption in comparison with women. It is possible that women have an increased plasmin activity in the microcirculation due to the higher concentration of soluble fibrin that forms micro-clots (plasminogen activator stimulator) that may lead to a decrease in the level of thrombomodulin at the surface of blood vessels and a lower activation of protein $\mathrm{C}$ in comparison with men.

Thus, an increase in the concentration of soluble fibrin in plasma of patients, which accompanies activation of the coagulation system and the related system of fibrinolysis and protein $\mathrm{C}$, is also accompanied by changes in the values of parameters in the system of determination of hemostatic potential and in the system of molecular markers of hemostasis. On the whole, these changes are aimed at increasing the ability of hemostasis system in patient plasma to form larger and more stable fibrin clots. On the other hand, a more subtle differentiation of patients with the degree of activation of the plasma coagulation system may allow obtaining more information to evaluate the state of the hemostasis system and predict the direction of its change in patients.

The obtained data also indicate that the parameters of the hemostasis system state in patients with CKD, found by determination of values of the total hemostasis potential in plasma in vitro and the concentrations of molecular markers characteristic of the in vivo state, are greater in women than in men, and indicate a higher activity of plasma hemostasis system in women.

Analysis of correlation between the parameters of hemostasis system and concentrations of molecular markers of the hemostasis system. The division of patients in groups, depending on the degree of activation of plasma coagulation system, has shown that increasing concentrations of soluble fibrin in the blood plasma of patients increases the magnitude of other parameters of the OHP and the concentrations of the molecular markers of the hemostasis system. In this connection, the question arose about the availability and power of the interconnection of individual parameters of these systems among themselves, within each system, between systems and depending on the experience of hemodialysis. For this purpose, Pearson's pairwise correlation analysis was performed between the parameters of the both systems.

It was found that the hemodialysis experience is not related to parameters of any of the systems, since the values of the obtained correlation coefficients are unreliable, $P>0.05$. There were no correlations found in pairs OHP-sf and OHP-DD. Strong, very strong and sometimes intermediate relationship was observed for pairs within the group of parameters associated with the determination of OHP, namely OHP - H, OHP - L, OHP - T, OHP - CP, OHP - FP, CP - FP, FP - H and FP - L (Table 3), as well as with determination of OHP for patients with myocardial infarction, stroke and hip disease [4]. At the same time, coefficients in groups with different concentrations of soluble fibrin showed the same order of relationship strength as in the group "all patients".

Attention is drawn to the results obtained in the analysis of the relationship between the parameters of the system OHP and the system of molecular markers. Correlation coefficients for all pairs of the group "all patients" (88 patients, including 52 men and 36 women) showed a moderate, weak, and very weak link (Table 3). However, for those parameters of the pairs in the subgroups of men and women, where the correlation was found, the correlation coefficients significantly increased with increasing concentrations of soluble fibrin from the weak $(<0.5)$ and mean $(0.5-0.7)$ to the strong $(>0.7)$ and very strong $(>0.9)$ except for pairs of parameters OHP Fg, FP - Fg, H - Fg for women. The second important feature in the men groups was the lack of correlation in the pairs of parameters OHP - PC, CP - PC, FP - Fg, FP - PC and Fg - PC. In these pairs within groups of women the average, strong and very strong correlation was observed. An important fact was the presence of a strong negative correlation in women between the concentration of protein $\mathrm{C}$ and parameters such as OHP, CP, FP and Fg. In men, the correlation was observed for the pairs of parameters Sf $\mathrm{DD}, \mathrm{H}$ - Fg, FP - Fg, OHP - Fg of medium, strong and very strong strength, respectively. It is noteworthy that in these pairs of parameters we have not observed correlation in men groups under the first two concentrations of soluble fibrin, namely sf $<3$ and $3<\mathrm{sf}<4$, when the inflammatory process in patients is likely observed in the remission stage. 
Table 3. Correlation coefficients of parameters of hemostatic potential, concentration of soluble fibrin, D-dimer, fibrinogen and protein C in blood plasma of patients with CKD of VD stage (glomerulonephritis) undergoing hemodialysis (men $-n=52$, women $-n=36$, all patients $-n=88$ ). Each group of patients is divided into three subgroups, depending on the concentration of soluble fibrin in the plasma: 15 men and 13 women with a concentration of $s f<3 ; 25$ men and 13 women with a concentration of $3<s f<4$; 12 men and 10 women with a concentration of $s f>4$. For all presented correlation coefficients $P<0.05$. n.s. is an unreliable value, $P>0.05$

\begin{tabular}{|c|c|c|c|c|c|}
\hline Parametrs & Patients & All patients & $\mathrm{sf}<3$ & $3<\mathrm{sf}<4$ & $\mathrm{sf}>4$ \\
\hline \multirow[t]{3}{*}{ OHP - Fg } & All patients & 0.45 & 0.30 & 0.37 & 0.72 \\
\hline & Men & 0.32 & n.s. & n.s. & 0.91 \\
\hline & Women & 0.63 & 0.50 & 0.54 & 0.64 \\
\hline OHP - PC & Women & -0.51 & n.s. & n.s. & -0.81 \\
\hline \multirow[t]{3}{*}{$\mathrm{CP}-\mathrm{Fg}$} & All patients & 0.40 & n.s. & n.s. & 0.68 \\
\hline & Men & n.s. & n.s. & n.s. & 0.78 \\
\hline & Women & 0.65 & 0.54 & 0.65 & 0.88 \\
\hline $\mathrm{CP}-\mathrm{PC}$ & Women & -0.25 & -0.14 & -0.70 & -0.85 \\
\hline FP - Fg & Women & 0.61 & 0.52 & 0.60 & 0.68 \\
\hline FP - PC & Women & -0.51 & -0.30 & n.s. & -0.93 \\
\hline \multirow[t]{2}{*}{$\mathrm{H}-\mathrm{Fg}$} & Men & n.s. & n.s. & n.s. & 0.85 \\
\hline & Women & 0.59 & 0.52 & 0.59 & 0.46 \\
\hline $\mathrm{Fg}-\mathrm{PC}$ & Women & -0.42 & n.s. & n.s. & -0.73 \\
\hline Sf - DD & Men & 0.51 & n.s. & n.s. & 0.62 \\
\hline \multirow[t]{3}{*}{ OHP - H } & All patients & 0.87 & 0.95 & 0.93 & 0.83 \\
\hline & Men & 0.88 & 0.96 & 0.92 & 0.82 \\
\hline & Women & 0.88 & 0.93 & 0.93 & 0.82 \\
\hline \multirow[t]{3}{*}{ OHP - L } & All patients & 0.74 & 0.68 & 0.78 & 0.72 \\
\hline & Men & 0.78 & 0.57 & 0.76 & 0.76 \\
\hline & Women & 0.70 & 0.72 & 0.61 & 0.63 \\
\hline \multirow[t]{3}{*}{ OHP - T } & All patients & 0.77 & 0.79 & 0.71 & 0.73 \\
\hline & Men & 0.82 & 0.85 & 0.65 & 0.76 \\
\hline & Women & 0.71 & 0.74 & 0.59 & 0.65 \\
\hline \multirow[t]{3}{*}{ OHP - FP } & All patients & 0.68 & 0.58 & 0.74 & 0.64 \\
\hline & Men & 0.60 & n.s. & 0.84 & 0.60 \\
\hline & Women & 0.84 & 0.78 & 0.65 & 0.93 \\
\hline \multirow[t]{3}{*}{$\mathrm{CP}-\mathrm{FP}$} & All patients & 0.88 & 0.64 & 0.87 & 0.83 \\
\hline & Men & 0.79 & n.s. & 0.81 & 0.94 \\
\hline & Women & 0.93 & 0.90 & 0.94 & 0.96 \\
\hline
\end{tabular}

In contrast to parameters of the hemostatic potential, a strong negative correlation was found only in the system of parameters in vivo between concentrations of Fg and PC, and there was a medium strength link between the main markers of the he- mostasis system Sf and DD dimer. It is important to note that the concentration of DD dimer did not correlate with other parameters at all concentrations of sf. It is obvious that the level of D-dimer is regulated by the level of microclots, which are the stimulator 


\section{System of coagulation}

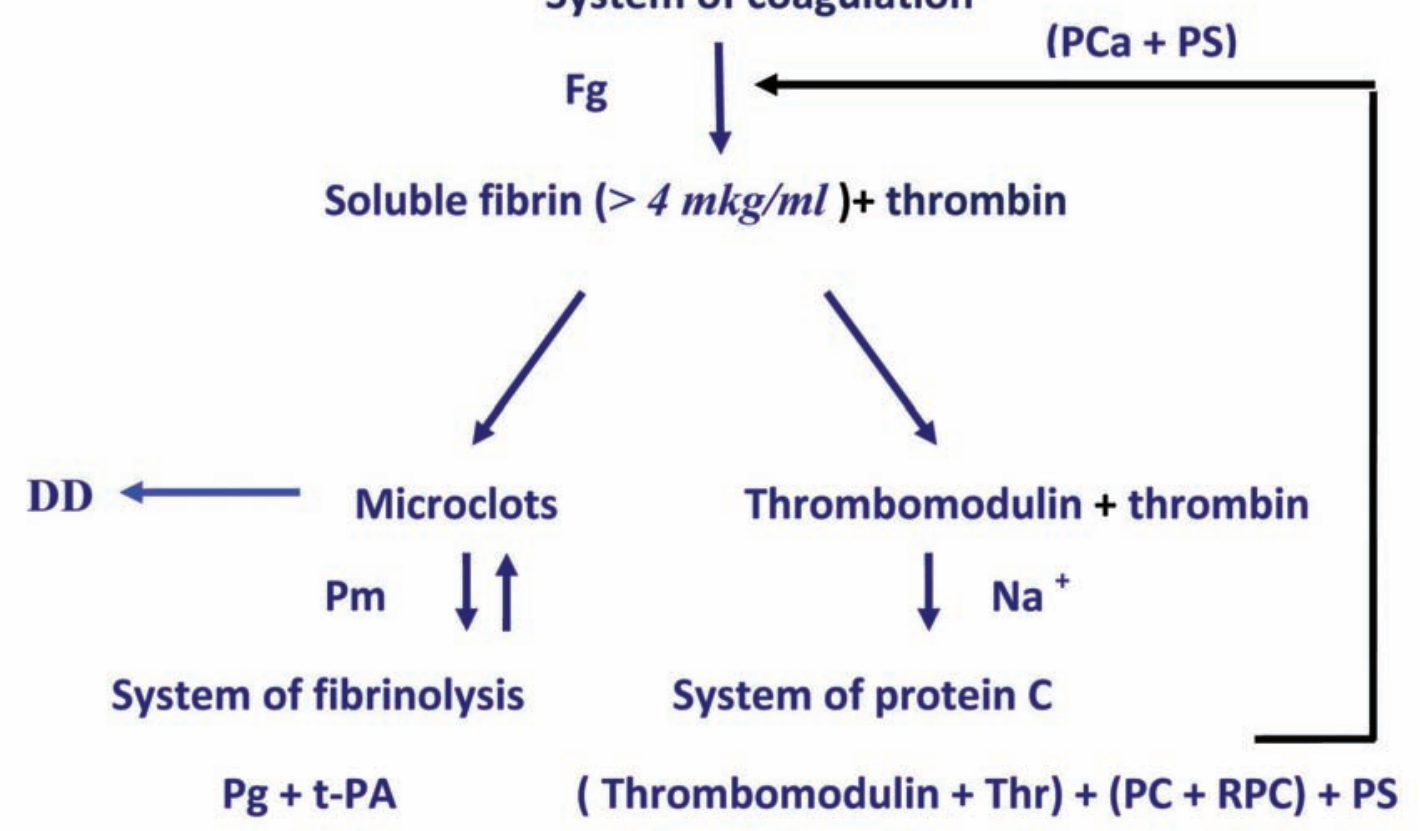

Fig. 5. Scheme of formation and interconnections of molecular markers of the humoral system components of hemostasis in plasma of patients with CKD, stage VD at a concentration of soluble fibrin $>4 \mu \mathrm{g} / \mathrm{ml}$. Pg-plasminogen, Pm-plasmin, Thr-thrombin, PS-protein S, RPC-endothelial protein C receptor; $P C a$ - protein C activated

of plasmin formation in the system of microcirculation, and factors influencing their formation are not related to the systems under investigation (Fig. 5).

Thus, we have found that the correlation between the parameters in both systems is growing with the increase of concentration of soluble fibrin in the blood plasma. In such pairs one Fg is one of the participants in men, and protein $\mathrm{C}$ - in women. In both cases, the level of connection increases to strong or very strong. At the same time the positive correlation in men increases suddenly at a concentration of soluble fibrin $>4 \mu \mathrm{g} / \mathrm{ml}$. At such a concentration of soluble fibrin, the concentration of fibrinogen begins to decrease (Table 2). However, the balanced character of the interaction of the system of coagulation and fibrinolysis (the correlation coefficient of the pair OHP-Fg - 0.91), the effective removal of $\mathrm{D}$-dimer from the bloodstream, activity of the PC system maintain a balance between the systems of coagulation, fibrinolysis and Pc.

Similarly, the negative correlation of pairs with the participation of protein $\mathrm{C}$ and parameters of hemostasis potential and $\mathrm{Fg}$ in women also increases. Obviously, both the protein $\mathrm{C}$ system and the fibrinolysis system are strongly activated at the activation level of the coagulation system, which corresponds to the increase in the concentration of sf $>4 \mu \mathrm{g} / \mathrm{ml}$. However, in women, an average degree of association between OHP and Fg is observed, pointing to weak regulation by $\mathrm{PCa}$ activation of fibrinogen in fibrin under the action of thrombin. As is known a soluble fibrin is a blood thrombin transporter that allows the "slow" form of thrombin to be dissociated into microcirculation and bind to thrombomodulin, causing activation of protein $\mathrm{C}$, which in turn is bound to the $\mathrm{PC}$ receptor [20-22]. The presence in the women blood plasma a PCa inhibitor, high level of sodium ions inhibits activation of PC by thrombin, which leads to further increasing in the concentration of soluble fibrin. At such concentrations of soluble fibrin, the probability of formation of microclots increases: they stimulate the activation of the fibrinolytic system and microclots dissolution under the action of plasmin with formation of DD fragments, which we observed in Table 3. The general scheme of interaction of coagulation, fibrinolysis and PC systems in the blood plasma hemostasis is shown in the scheme (Fig. 5). 


\section{ЗАГАЛЬНИЙ ГЕМОСТАТИЧНИЙ ПОТЕНЦАЛ ПЛАЗМИ КРОВІ І ЙОГО ЗВ'ЯЗОК ІЗ ДЕЯКИМИ МОЛЕКУЛЯРНИМИ МАРКЕРАМИ СИСТЕМИ ГЕМОСТАЗУ У ХВОРИХ НА ХРОНІЧНІ ЗАХВОРЮВАННЯ НИРОК VD СТАДIÏ}

\author{
Б. Г. Сторожук' , Л. В. Пирогова ${ }^{2}$, \\ T. М. Чернишенко $\sigma^{2}$ О. П. Костюченко ${ }^{2}$, \\ I. М. Колеснікова ${ }^{2}$, Т. М. Платонова ${ }^{2}$, \\ О. Б. Сторожук', Л. О. Сторожук ${ }^{1}$,

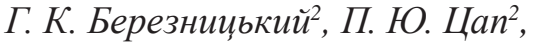 \\ О. О. Масенко ${ }^{2}$, С. М. Макогоненко ${ }^{2}$, \\ Е. В. Луговськой
}

\author{
${ }^{1}$ Вінницький національний медичний \\ університет ім. М. І. Пирогова, Україна; \\ ${ }^{2}$ Інститут біохімії ім О.В.Палладіна \\ НАН України, Київ; \\ e-mail: makogonenko@biochem.kiev.ua
}

\begin{abstract}
Визначали величини загального, фібринолітичного потенціалу та потенціалу зсідання плазми крові за методом глобального потенціалу M. Blomback, а також величини концентрацій молекулярних маркерів системи гемостазу: розчинного фібрину (sf), D-димеру, фібриногену (Fg) і протеїну C (88 хворих, із них 52 - чоловіки, 36 - жінки). Показано, що активність системи гемостазу в жінок вірогідно вище, ніж у чоловіків. Розподіл хворих за трьома групами залежно від концентрації sf: менше норми $-\mathrm{sf} \leq 3$, близько норми $-3<\mathrm{sf}<4$ та більше норми - sf $>4$ мкг/мл дозволив встановити підвищення значень параметрів гемостатичного потенціалу і концентрацій молекулярних маркерів залежно від концентрації sf у групах хворих. Парний кореляційний аналіз зв'язку між параметрами гемостатичного потенціалу та концентраціями молекулярних маркерів виявив збільшення сили зв'язку до сильного та дуже сильного між параметрами систем зсідання, фібринолізу i протеїну $\mathrm{C}$ за підвищення концентрації розчинного фібрину в плазмі крові хворих.
\end{abstract}

К люч о в і с ло в а: гемостатичний потенціал плазми крові, розчинний фібрин, D-димер, фібриноген, протеїн C.

\section{ОБЩИЙ ГЕМОСТАТИЧЕСКИЙ \\ ПОТЕНЦИАЛ ПЛАЗМЫ КРОВИ \\ И ЕГО СВЯЗЬ С НЕКОТОРЫМИ \\ МОЛЕКУЛЯРНЫМИ МАРКЕРАМИ \\ СИСТЕМЫ ГЕМОСТАЗА У \\ БОЛЬНЫХ ХРОНИЧЕСКИМИ \\ ЗАБОЛЕВАНИЯМИ ПОЧЕК VD СТАДИИ}

\author{
Б. Г. Сторожук', Л. В. Пирогова ${ }^{2}$, \\ Т. М. Чернышенко ${ }^{2}$ Е. П. Костюченко ${ }^{2}$, \\ И. Н. Колесникова ${ }^{2}$, Т. М. Платонова ${ }^{2}$, \\ О. Б. Сторожук 1 Л. О. Сторожук ${ }^{1}$,

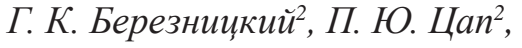 \\ А. А. Масенко ${ }^{2}$ Е. М. Макогоненко ${ }^{2}$, \\ Э. В. Луговской
}

\begin{abstract}
${ }^{1}$ Винницкий национальный медицинский университет им. Н. И. Пирогова. Украина; ${ }^{2}$ Институт биохимии им. А. В. Палладина НАН Украины, Киев;

e-mail: makogonenko@biochem.kiev.ua
\end{abstract}

Определяли величины свертывающего, общего и фибринолитического потенциала плазмы крови методом глобального потенциала M. Blomback, а также величины концентраций молекулярных маркеров системы гемостаза: растворимого фибрина (sf), D-димера, фибриногена $(\mathrm{Fg})$ и протеина C (88 больных, из них 52 - мужчины, 36 - женщины). Показано, что активность системы гемостаза у женщин достоверно выше таковой у мужчин. Распределение больных по трем группам в зависимости от концентрации sf: меньше нормы $-\mathrm{sf} \leq 3$, около нормы $-3<\mathrm{sf}<4$ и больше нормы - sf $>4$ мкг/мл позволило установить, что значения параметров как гемостатического потенциала, так и концентраций молекулярных маркеров увеличиваются с увеличением концентрации sf в группах больных. Парный корреляционный анализ связи между параметрами гемостатического потенциала и концентрациями молекулярных маркеров обнаружил повышение силы связи до уровня сильной и очень сильной между параметрами систем свертывания, фибринолиза и протеина С при увеличении концентрации растворимого фибрина в плазме крови больных.

К л ю ч в ы е с ло в а: гемостатический потенциал плазмы крови, растворимый фибрин, D-димер, фибриноген, протеин C. 


\section{References}

1. Di Cera E. Thrombin. Mol Aspects Med. 2008; 29(4): 203-254.

2. Esmon CT. The protein C pathway. Chest. 2003; 124(3 Suppl): 26S-32S.

3. Tanaka KA, Key NS, Levy JH. Blood coagulation: hemostasis and thrombin regulation. Anesth Analg. 2009; 108(5): 1433-1446.

4. Pyrogova LV, Chernyshenko TM, Kolesnikova IN, Platonova TN, Bereznitsky GK, Makogonenko YM, Lugovskoy EV. Level of overall hemostasis potential in donor and patient plasma in pathology. Ukr Biochem J. 2016; 88(2): 56-65.

5. Hood L. Systems biology and P4 medicine: past, present, and future. Rambam Maimonides Med J. 2013; 4(2): e0012.

6. Rublenko AM, Urvant LP, Makogonenko EM, Platonova TN, Tsap PU, Chernyshenko TM, Kolesnikova IM, Fishchenko VO, Lugovskoi EV. Effect of protein $\mathrm{C}$ activator on overall haemostasis potential in donor and hip arthroplasty patient plasma. Ukr Biokhim Zhurn. 2011; 83(5): 32-39. (In Ukrainian).

7. Lugovskoi EV, Kolesnikova IN, Lugovskaia NE, Litvinova LM, Gritsenko PG, Gogolinskaia GK, Liashko ED, Kostiuchenko EP, Remizovskiy GA, Pedchenko VN, Komisarenko SV. Quantification of D-dimer and soluble fibrin in blood plasma of patients with ischemic heart disease and hypotension. Ukr Biokhim Zhurn. 2004; 76(6): 136-141. (In Russian).

8. Lugovskoi EV, Kolesnikova IN, Lugovskaia NE, Gritsenko PG, Litvinova LM, Gogolinskaia GK, Liashko ED, Kostiuchenko EP, Golota VIa, Kurochka VV, Komisarenko SV. Soluble fibrin and D-dimer at normal pregnancy and pregnancy with risk of miscarriage. Ukr Biokhim Zhurn. 2006; 78(4): 120-129.(In Russian).

9. Hantgan RR, Hermans J. Assembly of fibrin. A light scattering study. J Biol Chem. 1979;254(22): 11272-11281.

10. Carr ME Jr, Hermans J. Size and density of fibrin fibers from turbidity. Macromolecules. 1978; 11(1): 46-50.

11. Makogonenko E, Tsurupa G, Ingham K, Medved L. Interaction of fibrin(ogen) with fibronectin: further characterization and localization of the fibronectin-binding site. Biochemistry. 2002; 41(25): 7907-7913.
12. Sakharov DV, Nagelkerke JF, Rijken DC. Rearrangements of the fibrin network and spatial distribution of fibrinolytic components during plasma clot lysis. Study with confocal microscopy. J Biol Chem. 1996; 271(4): 21332138.

13. Ariëns RA, Lai TS, Weisel JW, Greenberg CS, Grant PJ. Role of factor XIII in fibrin clot formation and effects of genetic polymorphisms. Blood. 2002; 100(3): 743-754.

14. Levi $M$, van der Poll $T$. Inflammation and coagulation. Crit Care Med. 2010; 38(2 Suppl): S26-S34.

15. Lugovskoy EV, Gritzenko PG, Lugovskaya NE, Kolesnikova IN, Komisarenko SV. Soluble fibrin: molecular structure and quantification. Lab Diagn. 2006; 3(37): 11-17.

16. Suenson E, Petersen LC. Fibrin and plasminogen structures essential to stimulation of plasmin formation by tissue-type plasminogen activator. Biochim Biophys Acta. 1986; 870(3): 510-519.

17. Lugovskoy EV, Makogonenko YM, Komisarenko SV. Molecular mechanisms of formation and degradation of fibrin. K.: Naukova dumka, 2013: 158-163.

18. Chernukha LM, Kashyrova EV, Lugovskoi EV, Komisarenko SV, Kolesnikova IM, Makogonenko YM, Platonova TN, Pyrogova LV, Gornickaya OV. Characteristics of haemostatic system state at arteriovenous forms of congenital vascular malformations. Novosti Khirurgii. 2014; 22(2): 191-198. (In Russian).

19. Carr ME Jr, Shen LL, Hermans J. Mass-length ratio of fibrin fibers from gel permeation and light scattering. Biopolymers. 1977; 16(1): 1-15.

20. Meh DA, Siebenlist KR, Mosesson MW. Identification and characterization of the thrombin binding sites on fibrin. $J$ Biol Chem. 1996; 271(38): 23121-23125.

21. Meh DA, Siebenlist KR, Brennan SO, Holyst T, Mosesson MW. The amino acid sequence in fibrin responsible for high affinity thrombin binding. Thromb Haemost. 2001; 85(3): 470-474.

22. Di Cera E. Thrombin as procoagulant and anticoagulant. J Thromb Haemost. 2007; 5(Suppl 1): 196-202.

Received 27.12.2017 